\title{
Surgery for lung adenocarcinoma with smokers' polycythemia: a case report
}

\author{
Yasoo Sugiura ${ }^{1 *}$, Etsuo Nemoto ${ }^{1}$, Hiromi Shinoda ${ }^{2}$, Naoya Nakamura ${ }^{3}$ and Shizuka Kaseda ${ }^{1}$
}

\begin{abstract}
Background: Smoking is a cause of cancer and polycythemia. Therefore, surgeons who treat patients with cancer may also encounter patients with polycythemia. However, few cases of surgical patients with polycythemia have been reported; in particular, a surgical case involving smokers' polycythemia has never been reported. We herein report a patient with lung cancer and smokers' polycythemia who successfully underwent lobectomy with control of hematocrit based on a modified formula in the perioperative period.
\end{abstract}

Case presentation: A 67-year-old man underwent abdominoperineal resection for rectal carcinoma in June 2008. A ground glass opacity had been identified in the upper lobe of the right lung and was gradually enlarging. In March 2012, bronchoscopic cytology for investigation of the mass revealed non-small cell lung cancer, suggesting primary lung non-small cell carcinoma (T1 bNOMO, Stage IA). When he was referred to our hospital for surgery, his complete blood count showed a red blood cell level of $6.50 \times 10^{6} / \mathrm{LL}$, hemoglobin of $21.0 \mathrm{~g} / \mathrm{dL}$, and hematocrit of $60.1 \%$. The hematologists' diagnosis was secondary polycythemia due to heavy smoking (smokers' polycythemia) because the white blood cell and platelet counts were within normal limits and the erythropoietin was not increased. We calculated the appropriate phlebotomy and infusion volumes based on a formula that we modified. After $550 \mathrm{~g}$ of blood was phlebotomized to reduce the hematocrit to approximately 55\%, video-assisted right lung upper lobectomy with lymph node dissection was performed in April 2012. The hematocrit was maintained at $<50 \%$ postoperatively, and the patient was uneventfully discharged on postoperative day 7 . The predictive hematocrit and measured hematocrit were very closely approximated in this case.

Conclusion: We experienced a patient with smokers' polycythemia who underwent right upper lobectomy for adenocarcinoma. The findings in this case report are meaningful for surgeons treating cancer patients because there are few reports discussing the perioperative care of surgical patients with polycythemia.

Keywords: Smokers' polycythemia, Phlebotomy, Predictive hematocrit, Lung cancer, Lung lobectomy

\section{Background}

Smoking is a cause of cancer and polycythemia [1,2]. Therefore, surgeons who treat patients with cancer may encounter cases of polycythemia. However, few surgical patients with cancer and polycythemia have been reported. We experienced a patient who underwent lung lobectomy for lung cancer and had secondary polycythemia due to smoking. The most frequent complication of polycythemia is thrombosis [3]. We managed this patient's hematocrit (HCT) to prevent thrombosis by performing phlebotomy and infusion based on a formula

\footnotetext{
*Correspondence: yasoos@hotmail.com

${ }^{1}$ National Hospital Organization, Kanagawa National Hospital, Pulmonary and Thoracic Surgery, 666-1 Ochiai, Hadano, Kanagawa 257-8585, Japan Full list of author information is available at the end of the article
}

that we modified. As a result, the predictive HCT and measured HCT were very closely approximated, and we succeeded in providing effective perioperative care. This report provides useful information for the management of surgical patients with polycythemia.

\section{Case presentation}

A 67-year-old man who underwent abdominoperineal resection for rectal carcinoma in June 2008 was evaluated for an abnormal chest shadow appearing as a ground glass opacity (GGO) in the right lung S1. It was gradually enlarging, and histology by brush cytology via bronchoscopy showed non-small cell lung cancer cells. He presented to our hospital for surgical treatment of the lung cancer (Figure 1).

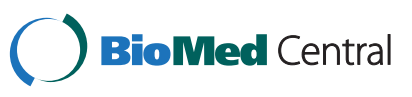



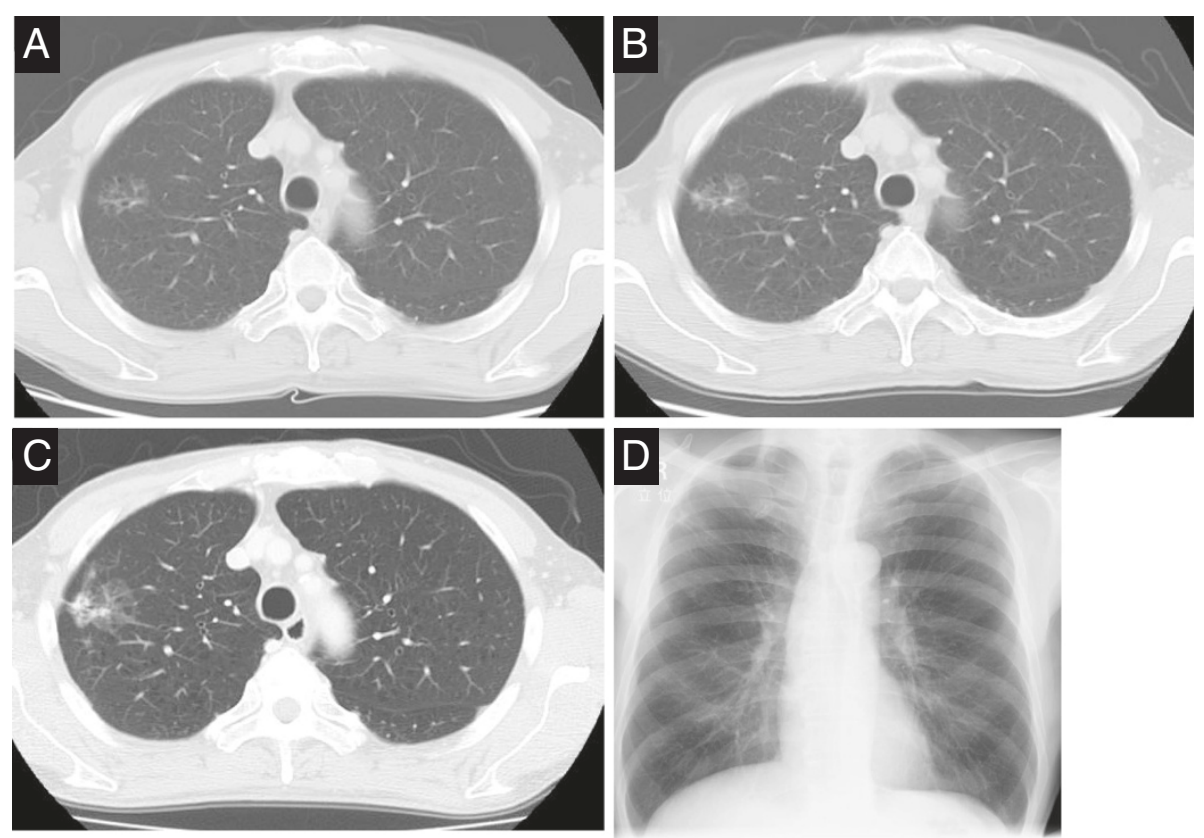

Figure 1 Chest computed tomography and X-ray photography. (A) Computed tomography, June 2009. (B) Computed tomography, January 2011. (C) Computed tomography, March 2012. (D) Chest X-ray photography, March 2012. The GGO at the lateral aspect of right S1 was enlarging, and it became a mass. GGO: ground glass opacity.

Table 1 Blood examination results on admission in March 2012

\begin{tabular}{|c|c|c|c|c|c|}
\hline $\mathrm{TP}$ & $7.5 \mathrm{~g} / \mathrm{dL}$ & WBC & $8.2 \times 10^{3} / \mu \mathrm{L}$ & $\mathrm{PaCO}_{2}$ & $39.8 \mathrm{mmHg}$ \\
\hline Alb & $4.5 \mathrm{~g} / \mathrm{dL}$ & $\mathrm{RBC}$ & $6.50 \times 10^{6} / \mu \mathrm{L}$ & $\mathrm{PaO}_{2}$ & $95.0 \mathrm{mmHg}$ \\
\hline AST/ALT & 24/18 IU/L & $\mathrm{Hb}$ & $21.0 \mathrm{~g} / \mathrm{dL}$ & $\mathrm{HCO}_{3}^{-}$ & $26.2 \mathrm{mmol} / \mathrm{L}$ \\
\hline LDH & $170 \mathrm{IU} / \mathrm{L}$ & $\mathrm{HCT}$ & $60.1 \%$ & $\mathrm{BE}$ & $1.9 \mathrm{mmol} / \mathrm{L}$ \\
\hline T. Bil & $1.4 \mathrm{mg} / \mathrm{dL}$ & MCV & $92.5 \mathrm{fl}$ & $\mathrm{O}_{2} \mathrm{Hb}$ & $94.3 \%$ \\
\hline ALP & $367 \mathrm{IU} / \mathrm{L}$ & $\mathrm{MCH}$ & $32.3 \mathrm{pg}$ & $\mathrm{COHb}$ & $2.3 \%$ \\
\hline Y-GTP & $102 \mathrm{IU} / \mathrm{L}$ & $\mathrm{MCHC}$ & $34.9 \mathrm{~g} / \mathrm{dL}$ & MetHb & $0.5 \%$ \\
\hline $\mathrm{BUN} / \mathrm{Cr}$ & $12.8 / 0.69 \mathrm{mg} / \mathrm{dL}$ & Plt & $216 \times 10^{3} / \mu \mathrm{L}$ & $\mathrm{SaO}_{2}$ & $97.0 \%$ \\
\hline UA & $9.0 \mathrm{mg} / \mathrm{dL}$ & Neut & $65.3 \%$ & & \\
\hline $\mathrm{Na} / \mathrm{Cl} / \mathrm{K}$ & 143/104/4.2 mEq/L & Lymph & $15.6 \%$ & & \\
\hline \multirow[t]{2}{*}{ T-Cho } & $184 \mathrm{mg} / \mathrm{dL}$ & Mono & $14.2 \%$ & & \\
\hline & & Eosino & $4.0 \%$ & & \\
\hline CEA & $7.4 \mathrm{ng} / \mathrm{mL}$ & Baso & $0.9 \%$ & & \\
\hline ProGRP & $60.6 \mathrm{pg} / \mathrm{mL}$ & & & & \\
\hline CYFRA & $1.7 \mathrm{ng} / \mathrm{mL}$ & & & & \\
\hline Erythropoietin & $8.8 \mathrm{mU} / \mathrm{mL}$ & & & & \\
\hline $\mathrm{CCr}$ & $104.6 \mathrm{~mL} / \mathrm{min}$ & & & & \\
\hline
\end{tabular}

The blood gas was analyzed in room air. The reference value of erythropoietin is $8-36 \mathrm{mU} / \mathrm{mL}$.

TP, total protein; Alb, albumin; AST, aspartate aminotransferase; ALT, alanine aminotransferase; LDH, lactase dehydrogenase; T. Bil, total bilirubin; ALP, alkaline phosphatase; Y-GTP, y glutamyl transpeptidase; BUN, blood urea nitrogen; $\mathrm{Cr}$, creatinine; UA, urinary acid; $\mathrm{Na}$, sodium; Cl, chlorine; $\mathrm{K}$, potassium; $\mathrm{T}-\mathrm{Cho}$, total cholesterol; CEA, carcinoembryonic antigen; ProGRP, pro-gastrin-releasing peptide; CYFRA, cytokeratin fragment 19; CCr, creatinine clearance; WBC, white blood cell; RBC, red blood cell; $\mathrm{Hb}$, hemoglobin; $\mathrm{HCT}$, hematocrit; $\mathrm{MCV}$, mean corpuscular volume; $\mathrm{MCH}$, mean corpuscular hemoglobin; MCHC, mean corpuscular hemoglobin concentration; Plt, platelet; Neut, neutrophil; Lymph, lymphocyte; Mono, monocyte; Eosino, eosinophil; Baso, basophil; PaCO ${ }_{2}$, arterial $\mathrm{CO}_{2}$ tension; $\mathrm{PaO}_{2}$, arterial $\mathrm{O}_{2}$ tension; $\mathrm{HCO}_{3}^{-}$, bicarbonate ion; $\mathrm{BE}$, base excess; $\mathrm{O}_{2} \mathrm{Hb}$, oxyhemoglobin; $\mathrm{COHb}$, carboxyhemoglobin; Met Hb, methemoglobin; $\mathrm{SaO}$, arterial oxygen saturation. 
Table 2 Course of CBC before surgery

\begin{tabular}{lccccccc}
\hline & June & June & Sep. & Apr. & Nov. & June & Feb. \\
& $\mathbf{2 0 0 8}$ & $\mathbf{2 0 0 9}$ & $\mathbf{2 0 0 9}$ & $\mathbf{2 0 1 0}$ & $\mathbf{2 0 1 0}$ & $\mathbf{2 0 1 1}$ & $\mathbf{2 0 1 2}$ \\
\hline $\begin{array}{l}\text { Tumor size in } \\
\text { maximum diameter } \\
(\mathrm{mm})\end{array}$ & & 27 & & & & 30 & 36 \\
$\mathrm{RBC}\left(\times 10^{6} / \mathrm{\mu L}\right)$ & 4.82 & 5.38 & 6.40 & 5.51 & 5.77 & 6.28 & 6.39 \\
$\mathrm{Hb}(\mathrm{g} / \mathrm{dL})$ & 15.3 & 18.1 & 20.5 & 18.2 & 19.5 & 20.6 & 21.1 \\
$\mathrm{HCT}(\%)$ & 44.0 & 50.2 & 58.2 & 52.7 & 54.3 & 57.2 & 60.8 \\
\hline
\end{tabular}

$\mathrm{RBC}$, red blood cell; $\mathrm{Hb}$, hemoglobin; $\mathrm{HCT}$, hematocrit.

His hypertension was being treated with $5 \mathrm{mg}$ of amlodipine a day. He had been a three-packs-a-day smoker for 40 years, and he stopped smoking 4 weeks before surgery.

The blood examination on admission in March 2012 suggested polycythemia based on a red blood cell (RBC) count of $6.50 \times 10^{6} / \mu \mathrm{L}$, hemoglobin $(\mathrm{Hb})$ of $21.0 \mathrm{~g} / \mathrm{dL}$, and HCT of $60.1 \%$. Other blood cells and erythropoietin were not increased (Table 1). His complete blood count had been almost within normal limits until June 2009. Since September 2009, the RBC count, Hb, and HCT had been increasing (Table 2). The size of the GGO and its solid component had also been enlarging. The respiratory function examination showed obstructive impairment based on a vital capacity (VC) of $5.19 \mathrm{~L}, \% \mathrm{VC}$ of $151.3 \%$, 1 second forced expiratory volume (FEV1.0) of $3.14 \mathrm{~L}$, FEV1.0\% of $63.7 \%$, \%FEV1.0 of $60.5 \%$ and diffusing capacity of the lung for carbon monoxide (DLCO) of $3.26 \mathrm{~mL} / \mathrm{min} / \mathrm{mmHg} / \mathrm{L}$.

Although a bone marrow examination was not performed, only one factor in the major and minor diagnostic criteria for polycythemia vera (PV) did not match $[4,5]$. In the major criteria, HCT was $>60 \%$, the cause of the secondary erythrocytosis was smoking, and splenomegaly was not present. In the minor criteria, the platelet count was $<400 \times 10^{3} / \mu \mathrm{L}$, the neutrophil count was $<12.5 \times 10^{6} / \mu \mathrm{L}$, and the serum erythropoietin level was within normal limits. Consultation with hematologists led us to conclude that these data were contradictive to a myeloproliferative disorder (e.g., chronic myeloid leukemia, polycythemia rubra vera, or essential thrombocythemia), and the diagnosis was smokers' polycythemia (SP).

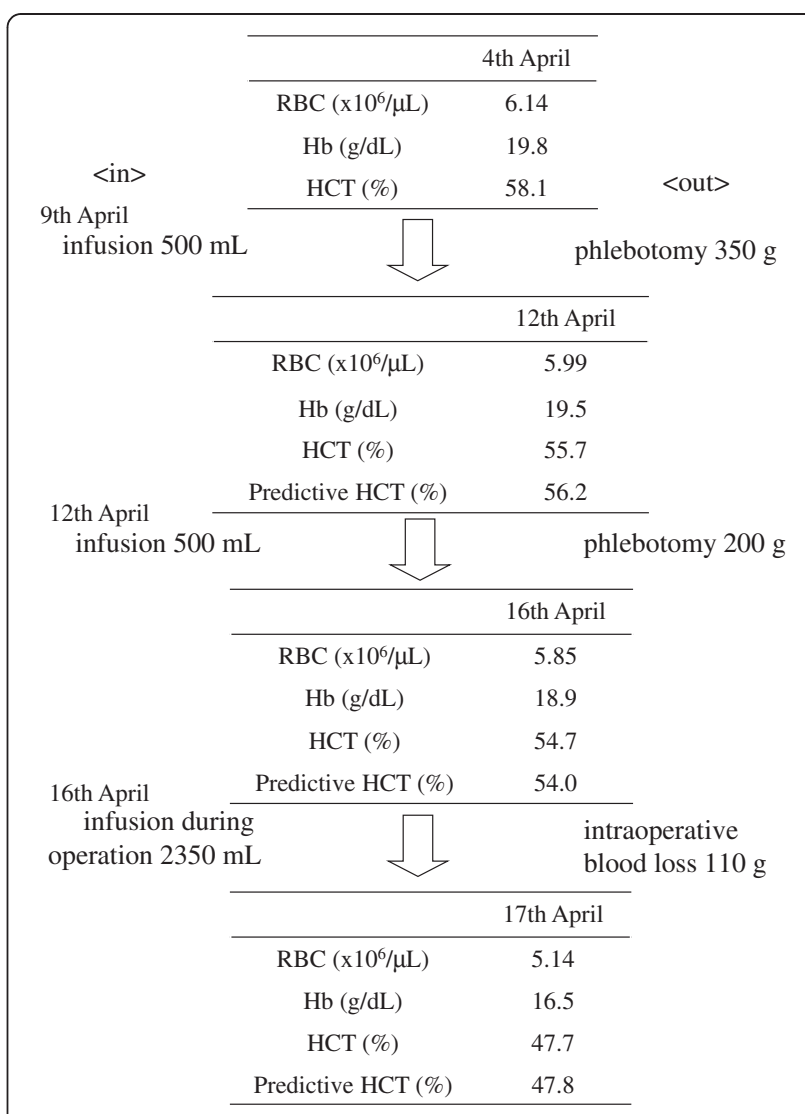

Figure 3 Predictive HCT and phlebotomy in the perioperative period. $\mathrm{HCT}$ : hematocrit.

We calculated the appropriate phlebotomy and infusion volumes based on a formula that we modified (Figure 2). A total of 350 and $200 \mathrm{~g}$ was phlebotomized 1 week and 4 days before the operation, respectively, to reduce the HCT to approximately $55 \%$. Video-assisted right lung upper lobectomy and lymph node dissection were then performed in April 2012. The total intraoperative infusion volume was $2350 \mathrm{~mL}(7.8 \mathrm{~mL} / \mathrm{kg} / \mathrm{hr})$, intraoperative urinary output was $500 \mathrm{~mL}$, and intraoperative blood loss was $110 \mathrm{~g}$ (Figure 3). We maintained the HCT at $<50 \%$, and the patient was uneventfully discharged on postoperative day 7 .

$$
H C T^{\prime}=\frac{\frac{H C T}{100} \times\left(B W \times 0.075-\frac{W p}{S G}\right)}{\left(B W \times 0.075-\frac{W p}{S G}+\frac{V i}{4}\right)} \times 100
$$

Figure 2 Formula for predictive HCT after phlebotomy. HCT: hematocrit, HCT': predictive HCT after phlebotomy, BW: body weight, Wp: weight of phlebotomy, SG: specific gravity, Vi: volume of infusion. 
Pathological findings revealed that the bronchioalveolar carcinoma component occupied $>90 \%$. Immunohistologic staining for erythropoietin was negative. The pathological diagnosis was primary lung adenocarcinoma, $42 \times 40 \times 26$ $\mathrm{mm}, \mathrm{pT} 2 \mathrm{aN0M0}$ Stage IB (lymph node station 2, 0/1; 7, $0 / 4 ; 10,0 / 7)$.

The serum erythropoietin level 1 month after discharge was normal at $11.2 \mathrm{mU} / \mathrm{dL}$, as before the operation. However, the $\mathrm{Hb}$ and $\mathrm{HCT}$ in November 2012 were $22.0 \mathrm{~g} / \mathrm{dL}$ and $61.0 \%$, respectively.

\section{Conclusion}

Smoking is one of the most notorious carcinogenic risk factors and a recognized cause of lung cancer [1]. Smoking is also a known cause of SP [2]. SP with hypertension is called Gaisböck syndrome and is frequently associated with cerebrovascular disease [6]. However, there are very few reports on surgery for patients with SP. Therefore, we reviewed the complications and treatments of PV [5,7-10]. According to the Polycythemia Vera Study Group, the most common cause of death in patients with polycythemia is thrombosis $[3,10]$. Thus, we formulated countermeasures to prevent the thrombosis during the perioperative period.

Cerebrovascular disease and high HCT in patients with SP are correlated, and treatments to prevent these complications include anticoagulants and/or antiplatelet agents and cytoreduction $[3,11,12]$. Thus, we chose to reduce the HCT before the operation because we had to be wary of using anticoagulants or antiplatelets during the perioperative period [13]. The optimal HCT is unclear in patients with SP, even in patients with PV [14], because, on theoretical grounds, erythrocytosis in this situation represents to a certain extent an "appropriate" physiological response to hypoxemia [15]. Thus, whatever the ideal HCT in cases of primary polycythemia, the corresponding ideal in cases of SP is likely to be higher [15]. We decided that the target HCT just before surgery was $55 \%$, considering the average amount of intraoperative blood loss and for lobectomy in our hospital.

The total circulating blood volume is almost $1 / 13$ (7.5\%) of body weight, the RBC mass is 24 to $30 \mathrm{~mL} / \mathrm{kg}$, and the plasma volume is 39 to $49 \mathrm{~mL} / \mathrm{kg}$ [16]. Approximately $25 \%$ of physiological saline remains in the vascular space, and the remaining $75 \%$ is distributed throughout the interstitial tissue [17]. We calculated the phlebotomy volume using the modified formula in Figure 2 [18]. Determination of the predictive HCT and measured HCT in the perioperative period is shown in Figure 3.

The most important condition in this case was that homeostasis was maintained because of the presence of normal renal function and the fact that the patient underwent elective surgery. There are many methods and approaches to accurate calculation of the total circulating blood volume. However, this formula would be reliable if we had assumed that the body fluid, excluding the phlebotomy and infusion volumes, was in a stationary state. Practically, the predictive HCT and measured HCT were very closely approximated in this case.

It is unknown why the polycythemia became obvious after June 2008 and erythrocytosis developed 8 months after surgery. However, Weinberg et al. reported that significant increases in the prevalence and frequency of mutation of the Janus kinase 2 (JAK2) gene, the protein of which is especially important for controlling the production of blood cells from hematopoietic stem cells, may be related to poor DNA repair in smokers as a result of the increased demand for erythrocyte production [19]. JAK2 mutation may have been present in this patient.

In conclusion, we experienced a patient with SP who underwent right upper lobectomy for adenocarcinoma. Smoking is a cause of cancer and polycythemia. Thus, this is a salutary case report for surgeons treating cancer patients because there are few reports discussing the perioperative care of surgical patients with polycythemia. This report is based on the experience of only one patient. Therefore, experience with surgical patients with SP should be accumulated and shared among surgeons to understand and improve treatment these cases.

\section{Consent}

Written informed consent for the perioperative care and operation in this case was obtained on admission in accordance with institutional guidance based on the Helsinki Declaration. At the time of discharge, we reconfirmed that the patient gave permission to publish a case report about his clinical course. A copy of the written consent is available for review by the Editor-in-Chief of the journal.

\section{Abbreviations}

GGO: Ground glass opacity; RBC: Red blood cells; Hb: Hemoglobin; HCT: Hematocrit; VC: Vital capacity; FEV 1.0: 1-second forced expiratory volume; DLCO: Diffusing capacity of the lung for carbon monoxide; SP: Smokers' polycythemia; JAK2: Janus kinase 2.

\section{Competing interests}

The author and co-authors have no potential conflict of interests to disclose. No financial or nonfinancial competing interests exist in this case report.

\section{Authors' contributions}

EN, SK, and YS operated on and treated this patient together in the perioperative period. HS determined the diagnosis by brush cytology via bronchoscopy as the primary physician. NN contributed to the pathological diagnosis and immunohistological chemistry of erythropoietin. SK was responsible for all aspects of management as president of Kanagawa National Hospital and chief of the Department of Pulmonary and Thoracic Surgery. All authors read and approved the final manuscript.

\section{Acknowledgements}

We thank Dr. Kei Tadume and his colleagues in Division of Hematology, Hadano Red Cross Hospital (Hadano, Japan) for the advice on diagnosis of smokers' polycythemia and for preparing this article for publication.

\section{Author details}

${ }^{1}$ National Hospital Organization, Kanagawa National Hospital, Pulmonary and Thoracic Surgery, 666-1 Ochiai, Hadano, Kanagawa 257-8585, Japan. ${ }^{2}$ Isehara 


\section{References}

1. Steliga MA, Dresler CM: Epidemiology of lung cancer: smoking, secondhand smoke, and genetics. Surg Oncol Clin N Am 2011, 20:605-618.

2. Smith JR, Landaw SA: Smokers' polycythemia. N Engl J Med 1978, 298:6-10.

3. Marchioli R, Finazzi G, Landolfi R, Kutti J, Gisslinger H, Patrono C, Marilus R, Villegas A, Tognoni G, Barbui T: Vascular and neoplastic risk in a large cohort of patients with polycythemia vera. J Clin Oncol 2005, 23:2224-2232.

4. Pearson TC, Messinezy M: The diagnostic criteria of polycythaemia rubra vera. Leuk Lymphoma 1996, 22(Suppl 1):87-93.

5. McMullin MF, Bareford D, Campbell P, Green AR, Harrison C, Hunt B, Oscier D, Polkey MI, Reilly JT, Rosenthal E, Ryan K, Pearson TC, Wilkins B, General Haematology Task Force of the British Committee for Standards in $\mathrm{H}$ : Guidelines for the diagnosis, investigation and management of polycythaemia/erythrocytosis. Br J Haematol 2005, 130:174-195.

6. Spiers AS, Levine M: Smokers' polycythaemia. Lancet 1983, 1:120

7. Landaw SA: Polycythemia vera and other polycythemic states. Clin Lab Med 1990, 10:857-871.

8. Marchioli R, Finazzi G, Specchia G, Masciulli A, Mennitto MR, Barbui T: The CYTO-PV: A large-scale trial testing the intensity of CYTOreductive therapy to prevent cardiovascular events in patients with polycythemia vera. Thrombosis 2011, 2011:794240.

9. Tefferi A: Polycythemia vera and essential thrombocythemia: 2012 update on diagnosis, risk stratification, and management. Am J Hematol 2012, 87:285-293.

10. Wasserman $L R$, Berk PD, Berlin NI: Treatment of polycythemia vera: a summary of clinical trials conducted by the Polycythemia Vera Study Group. In Polycythemia vera and the myeloproliferative disorders. Edited by Wasserman LR, Berk PD, Berlin NI. Philadelphia: WB Saunders; 1995:166.

11. Raval M, Paul A: Cerebral Venous Thrombosis and Venous Infarction: Case Report of a Rare Initial Presentation of Smoker's Polycythemia. Case Rep Neurol 2010, 2:150-156.

12. De Stefano V, Za T, Rossi E, Vannucchi AM, Ruggeri M, Elli E, Mico C, Tieghi A, Cacciola RR, Santoro C, Gerli G, Vianelli N, Guglielmelli P, Pieri L, Scognamiglio F, Rodeghiero F, Pogliani EM, Finazzi G, Gugliotta L, Marchioli R, Leone G, Barbui T, Party GC-W: Recurrent thrombosis in patients with polycythemia vera and essential thrombocythemia: incidence, risk factors, and effect of treatments. Haematologica 2008, 93:372-380.

13. Newton LK: Neurologic complications of polycythemia and their impact on therapy. Oncology (Williston Park) 1990, 4:59-64. discussion 64-56.

14. Di Nisio M, Barbui T, Di Gennaro L, Borrelli G, Finazzi G, Landolfi R, Leone G, Marfisi R, Porreca E, Ruggeri M, Rutjes AW, Tognoni G, Vannucchi AM, Marchioli R, European Collaboration on Low-dose Aspirin in Polycythemia Vera I: The haematocrit and platelet target in polycythemia vera. $\mathrm{Br} J$ Haematol 2007, 136:249-259.

15. Thakur KT, Westover MB: Cerebral infarction due to smoker's polycythemia. BMJ Case Rep 2011, doi:10.1136/bcr.08.2011.4714.

16. Pearson TC, Guthrie DL, Simpson J, Chinn S, Barosi G, Ferrant A, Lewis SM, Najean $Y$ : Interpretation of measured red cell mass and plasma volume in adults: Expert Panel on Radionuclides of the International Council for Standardization in Haematology. Br J Haematol 1995, 89:748-756.

17. Yeager MP, Spence BC: Perioperative fluid management: current consensus and controversies. Semin Dial 2006, 19:472-479.

18. Fujioka S: Formula for a prediction of venous hematocrit value following phlebotomy and infusion in polycythemia vera. Med Biol 1988, 117:247-249.

19. Weinberg I, Borohovitz A, Krichevsky S, Perlman R, Ben-Yehuda A, Ben-Yehuda D: Janus kinase V617F mutation in cigarette smokers. Am J Hematol 2012, 87:5-8.

\section{doi:10.1186/1756-0500-6-38}

Cite this article as: Sugiura et al:: Surgery for lung adenocarcinoma with smokers' polycythemia: a case report. BMC Research Notes 2013 6:38.

\section{Submit your next manuscript to BioMed Central and take full advantage of:}

- Convenient online submission

- Thorough peer review

- No space constraints or color figure charges

- Immediate publication on acceptance

- Inclusion in PubMed, CAS, Scopus and Google Scholar

- Research which is freely available for redistribution

Submit your manuscript at www.biomedcentral.com/submit
C Biomed Central 